\title{
A new species of Hornstedtia and a new species record of Globba (Zingiberaceae) from Palawan, Philippines
}

\author{
R.V.A. $\operatorname{Docot}^{1}$, N.P. Mendez ${ }^{2,3}$ \& C.B.M. Domingo ${ }^{4}$ \\ ${ }^{1}$ Department of Biological Sciences, Institute of Art and Sciences, \\ Far Eastern University, Nicanor Reyes Sr. Street, Sampaloc 1015, Manila, Philippines \\ dukerudolph@gmail.com \\ 2 Department of Biology, College of Arts and Sciences, \\ Central Mindanao University, University Town, Musuan, \\ 8710 Bukidnon, Philippines \\ ${ }^{3}$ Centre for Biodiversity Research and Extension in Mindanao (CEBREM), \\ Central Mindanao University, University Town, Musuan, \\ 8710 Bukidnon, Philippines \\ ${ }^{4}$ The Graduate School, University of Santo Tomas, España Boulevard, \\ Sampaloc 1008, Manila,Philippines
}

\begin{abstract}
During recent botanical exploration in the province of Palawan, Philippines specimens were collected of a new species, Hornstedtia crispata Docot, and a new species record for the Philippines, Globba francisci Ridl., both from the ginger family Zingiberaceae. The new species is described and illustrated here along with an assessment of its conservation status.
\end{abstract}

Keywords. Borneo, endangered, Globba aurea, Hornstedtia hainanensis, Hornstedtia sanhan

\section{Introduction}

Palawan is an archipelagic province comprising of approximately 1,780 islands and islets at about $14,897 \mathrm{~km}^{2}$, making it the largest province in the Philippines (Fernandez et al., 2002). About $48 \%$ of the province is covered with vegetation, including tropical lowland evergreen rainforest, lowland semi-deciduous (seasonal/monsoon) forest, montane forest, and forest-over-limestone (PCSDS, 2015). Within this remaining forest are unique species of terrestrial flora and fauna, including 1700-3500 angiosperms, of which 15-20\% are endemic to the country (Sopsop \& Buot, 2009).

There is strong evidence that Borneo and Palawan were once connected by a land bridge based on bathymetric data (Woodruff, 2010) and from animal distributions (Heaney, 1986). This hypothesis is further supported by plant distributions (e.g. Poulsen \& Docot, 2018 for Etlingera sessilanthera R.M.Sm.) and through biogeographical studies using molecular data to explain colonisation of the Philippines from Borneo via Palawan (e.g. Brown \& Guttman, 2002 for Rana), or the other way around (e.g. Hughes et al., 2015 for Begonia L. sect. Baryandra A.DC.) Despite these efforts, further studies are still needed to support this hypothesis. 
Our knowledge of the Zingiberaceae of the Philippines has been updated as a result of recent botanical explorations focused on the collection of gingers (e.g. Naive, 2017; Naive \& Alejandro, 2018; Naive et al., 2018; Ambida et al., 2018; Poulsen \& Docot, 2018; Acma et al., 2019; Docot et al., 2019a, b). Ridley (1905) enumerated 19 species of Philippine Zingiberaceae but now 122 species are known, of which 68\% are endemic (Pelser et al., 2011 onwards; Zingiberaceae Resource Centre, 2019). Thirteen of these species occur in Palawan, five of which are endemic to the province (see Table 1 for a list of species in Palawan).

Hornstedtia Retz., as currently circumscribed, comprises c. 40 species distributed from the Himalayas to Queensland with a centre of diversity in continental Southeast Asia and Malesia. Sixteen species are found in Borneo (Lamb et al., 2013; Zingiberaceae Resource Centre, 2019). The genus can be easily recognised by the involucre of tightly overlapping sterile bracts that enclose the flowers near or at the uppermost part of the corolla tube and by the flat receptacle or condensed rachis (Smith, 1985). In the Philippines, Hornstedtia is represented by six species of which five are endemic and one, Hornstedtia havilandii (K.Schum.) K.Schum., is also found in Borneo (Pelser et al., 2011 onwards).

Globba L. species are distributed from Sri Lanka to Australia with a centre of distribution in monsoonal continental Southeast Asia (Williams et al., 2004). Members of this genus are easily distinguished by their small, delicate flowers with small labellum and elongated, arched stamen (Smith, 1988; Leong-Škorničková \& Newman, 2015). A total of eight species of Globba are currently known in the Philippines, all of which are endemic except Globba marantina L., a species which is naturalised in tropical regions around the world (Pelser et al., 2011 onwards).

Botanical fieldwork focused on collecting gingers conducted by the authors in Palawan in 2017-2018 led to the collection of unidentified Globba and Hornstedtia species. After careful morphological comparison with known Philippine species and those occurring on neighbouring islands (e.g. Borneo and Sulawesi), the authors concluded that the Hornstedtia species is new to science, and the Globba species is Globba francisci Ridl., a species hitherto endemic to Borneo (Lamb et al., 2013). The new species is described and illustrated here along with an assessment of its conservation status. It is likely that there are still numerous species awaiting discovery in Palawan and many species already known from Borneo will eventually be discovered in Palawan or vice versa.

\section{Materials and methods}

Herbarium collections, including high-resolution images of specimens, from $\mathrm{BISH}$, BM, BO, E, F, FEUH, G, GH, K, L, MO, NY, P, PNH, S, SING, U, US, USTH and $\mathrm{Z}$, along with published morphological descriptions of most similar species (e.g. Smith, 1988; Newman, 1995; Ye et al., 2018), especially those from the Philippines and neighbouring islands, were examined and compared to our recently collected specimens. Specimens seen only as a digital image available online are denoted 
Table 1. The 15 Zingiberaceae species currently known in Palawan including their distribution status in the Philippines and publication record for Palawan. An asterisk $\left(^{*}\right)$ indicates that the species is endemic in Palawan.

\begin{tabular}{|c|c|c|}
\hline Species & Distribution & $\begin{array}{l}\text { First recorded in } \\
\text { Palawan }\end{array}$ \\
\hline Alpinia foxworthyi Ridl. * & Endemic & Ridley (1909) \\
\hline Alpinia galanga (L.) Willd. & $\begin{array}{l}\text { Widespread and } \\
\text { cultivated }\end{array}$ & Merrill (1923) \\
\hline Alpinia haenkei C.Presl & Endemic & Ridley (1909) \\
\hline Alpinia illustris Ridl. * & Endemic & Ridley (1909) \\
\hline Curcuma zedoaria (Christm.) Roscoe & $\begin{array}{l}\text { Widespread and } \\
\text { cultivated }\end{array}$ & Merrill (1923) \\
\hline Etlingera philippinensis (Ridl.) R.M.Sm. & Endemic & Ridley (1909) \\
\hline Etlingera sessilanthera R.M.Sm. & Native & $\begin{array}{l}\text { Poulsen \& Docot } \\
\text { (2018) }\end{array}$ \\
\hline $\begin{array}{l}\text { Geocharis fusiformis (Ridl.) R.M.Sm. var. } \\
\text { fusiformis }\end{array}$ & Endemic & $\begin{array}{l}\text { Pelser et al. ( } 2011 \\
\text { onwards) }\end{array}$ \\
\hline Globba aurea Elmer * & Endemic & Elmer (1915) \\
\hline Globba francisci Ridl. & Native & here \\
\hline Globba marantina $\mathrm{L}$. & $\begin{array}{l}\text { Widespread and } \\
\text { cultivated }\end{array}$ & Merrill (1923) \\
\hline Globba ustulata Gagnep. * & Endemic & Gagnepain (1901) \\
\hline Hornstedtia crispata Docot & Endemic & here \\
\hline $\begin{array}{l}\text { Wurfbainia hedyosma (I.M.Turner) } \\
\text { Škorničk. \& A.D.Poulsen }\end{array}$ & Endemic & Merrill (1923) \\
\hline $\begin{array}{l}\text { Wurfbainia palawanensis (Elmer) } \\
\text { Škorničk. \& A.D.Poulsen * }\end{array}$ & Endemic & Elmer (1915) \\
\hline
\end{tabular}

with an asterisk (*). The herbarium acronyms follow Thiers (continuously updated). The species description of the new species follows the style of recently published species of Hornstedtia (e.g., Leong-Škorničková et al., 2016; Ye et al., 2018) and the terminology in Beentje (2012).

The extent of occurrence (EOO) and area of occupancy (AOO) of the new species were calculated using the Geospatial Conservation Assessment Tool (GeoCAT) (Bachman et al., 2011: www.geocat.kew.org). These data were then compiled to assess its conservation status using the International Union for Conservation of Nature criteria (IUCN, 2016). Furthermore, the coordinates of the localities based on information 
on herbarium labels were collected and generated in QGIS v. 2.18 (Quantum GIS Development Team, 2016), creating a distribution map (Fig. 4).

\section{Taxonomy}

Hornstedtia crispata Docot, sp. nov.

Similar to Hornstedtia sanhan M.F.Newman but differs in the petiolate lamina (vs sessile); significantly wider lamina (10-16 vs $5-7 \mathrm{~cm}$ ); oblong labellum (vs spathulate); presence of a 3-4 $\mathrm{mm}$ long petaloid and crispate anther crest; and subglobose epigynous glands (vs subulate). - TYPE: Philippines, Luzon, Palawan, Brooke's Point, Barangay Malis, Mount Mantalingajan, $8^{\circ} 45^{\prime} 20.7^{\prime \prime N} 117^{\circ} 39^{\prime} 25.0^{\prime \prime} \mathrm{E}$, 1228 m, 28 September 2018, R. V.A. Docot et al. 0191 (holotype PNH [accession no. 256990]; isotypes FEUH incl. spirit, L, USTH). (Fig. 1 \& 2).

Terrestrial herb in loose clumps. Rhizome $1.5-3 \mathrm{~cm}$ in diameter, yellowish-brown, scales thick, brown. Leafy shoot $4-8 \mathrm{~m}$ tall, arching to various degrees, base swollen, $5-6 \mathrm{~cm}$ wide; sheath reticulated, reddish-green when young, becoming light green when mature, glabrous; ligule ovate, 15-20 × 10-15 mm, reddish when young, becoming mid green when mature, the centre sericeous, becoming glabrous towards the margin, apex rounded; petiole 15-25 mm long, reddish when young, becoming light green when mature; lamina oblong, 55-70 × 10-16 cm, mid to dark green above, paler beneath, glabrous on both sides, base rounded, apex acute, margin reddish, slightly undulate, ciliate. Inflorescence 7-13 $\times 4-6 \mathrm{~cm}$, emerging from the ground, receptacle flat, with many flowers, one open at a time; peduncle erect, $2-3 \mathrm{~cm}$ long, covered with thick and brown peduncular bracts; sterile bract ovate, largest 40-60 $\times 30-45 \mathrm{~mm}$, becoming narrower towards the centre of the inflorescence, lower half sericeous, the hairs white, upper half bright red, glabrous and coriaceous, margin entire, apex rounded and emarginate; fertile bract oblong, 40-55 $\times 15-25 \mathrm{~mm}$, split to the base, translucent white, apex acute; bracteole oblong, 20-30 $\times 7-12 \mathrm{~mm}$, split to the base, translucent white, apex acute; flower sessile, $8-10 \mathrm{~cm}$ long; calyx tubular, upper portion sub-inflated, 35-45 × 10-15 $\mathrm{mm}$ when flattened, white, glabrous except the pubescent base, coriaceous, apex 3-dentate, brownish; corolla tube 5-6 cm long, both ends reddish, the centre white, glabrous outside, pubescent inside; corolla lobes bright red, glabrous, apex rounded and cucullate; dorsal corolla lobe ovate, 25-30 $\times$ 15-25 mm; lateral corolla lobes oblong, 25-35 × 10-20 mm; labellum oblong, 30-45 $\times 15-20 \mathrm{~mm}$, thick, fleshy, and bright red at the centre, glabrous except the pubescent base, margin petaloid, crispate, white, apex entire, auricles absent at the base of the labellum; lateral staminodes absent; stamen 15-20 mm long, adnate to the base of the labellum; filament fully reduced; anther 15-20 × 5-7; theca yellowish, dehiscing throughout its length, pubescent; anther crest 3-4 $\times 6-7 \mathrm{~mm}$, petaloid, reddish-pink at the base, the crispate margin white; style 6-7 cm long, white, pubescent except the lower half; stigma ovoid in shape, c. $2 \mathrm{~mm}$ wide, ostiole pubescent and facing forwards; ovary 5-7 × 2-4 mm, subglobose, white, slightly pubescent, coriaceous; 

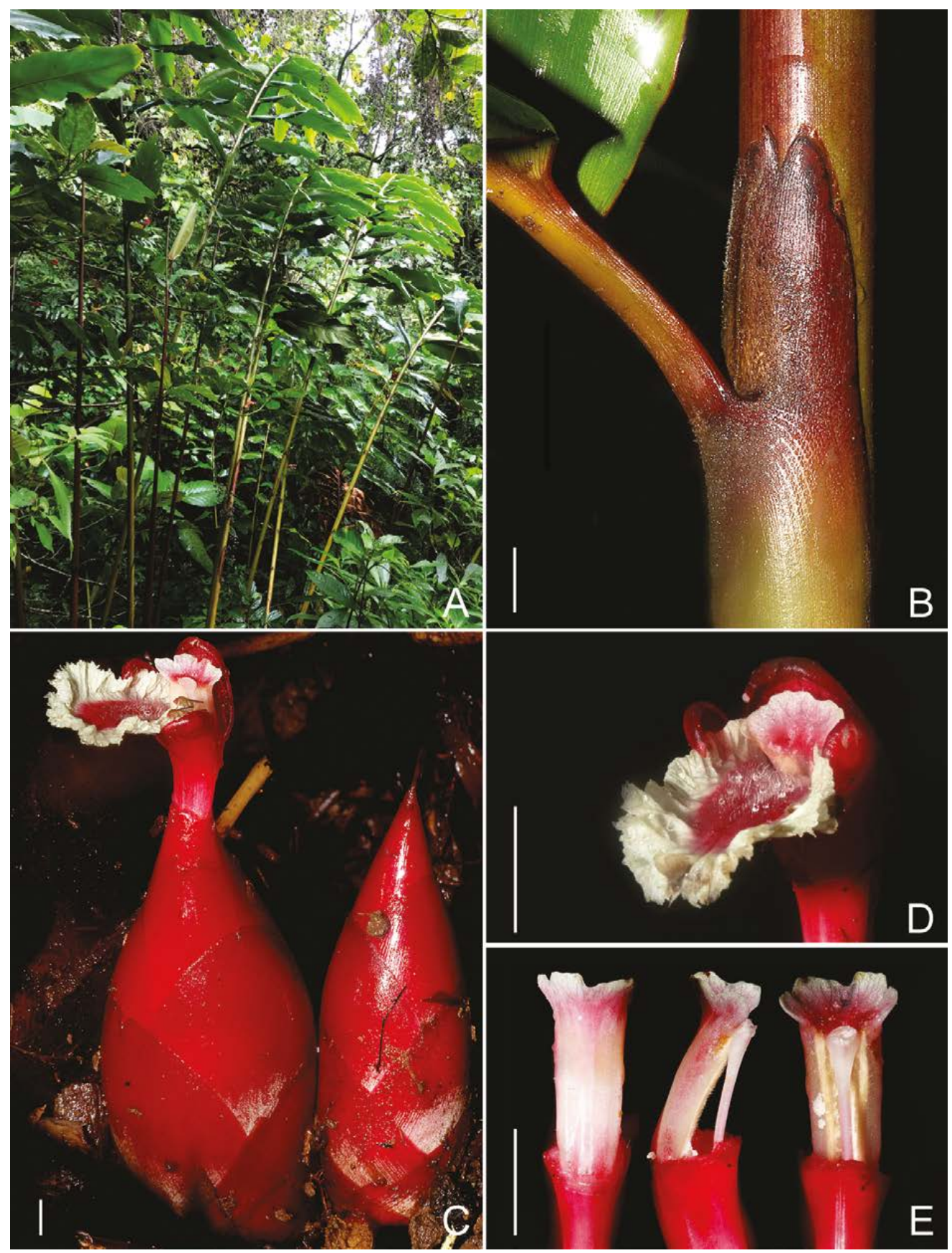

Fig. 1. Hornstedtia crispata Docot. A. Habit. B. Ligule. C. Inflorescences. D. Flower. E. Anther (back, side, and front view). All from the type specimen R.V.A. Docot et al. 0191 (type). Scale bars $=1 \mathrm{~cm}$. (Photos: R.V.A. Docot). 
epigynous glands subglobose, 2-3 $\mathrm{mm}$ long, enveloping the style. Infructescence 7-13 × 6-7 cm, with numerous fruit developing; fruit $2.3-3 \times 1-2.5 \mathrm{~cm}$, subglobose, slimy, whitish-pink, pubescent at both ends, glabrous at the middle, coriaceous, calyx persistent (observations taken from immature fruits, dimensions of mature fruits maybe larger); seed irregularly globose, 1-2 mm wide, brown with slimy white aril.

Distribution and habitat. Hornstedtia crispata is known only in Mount Mantalingajan, Brooke's Point, Palawan where it inhabits slopes of primary forest at 1000-1300 m.

Phenology. Both flowering and fruiting individuals were observed in late September.

Etymology. The specific epithet refers to the crispate anther crest.

Provisional IUCN conservation assessment. Based on the IUCN red list categories and criteria (IUCN, 2016), Hornstedtia crispata is categorised as Endangered EN B2ab(iii). The area of occupancy is estimated to be less than $500 \mathrm{~km}^{2}$ (total area of occupancy is c. $16 \mathrm{~km}^{2}$ ) and is known only at two locations on Mount Mantalingajan which is fortunately a protected area. Although the observed populations are within a protected area, the species may decline significantly if mining activities and conversion of forest into agricultural lands (e.g. rice plantations) are continued within the area.

Additional specimens examined. PHILIPPINES: Palawan: Brooke's Point, Barangay Malis, Mount Mantalingajan 8०45'19.8"N, 117³9'26.0"E, 1202 m, 28 September 2018, Docot et al. 0190 (FEUH, USTH).

Notes. No common names or uses were reported by our Palaw'an tribe local guides. The most similar species in morphology is Hornstedtia sanhan M.F.Newman of Vietnam (west of Palawan). Although of similar habit (leafy shoots of both species can reach at least $4 \mathrm{~m}$ in length), the lamina of Hornstedtia crispata has a 15-25 $\mathrm{mm}$ long petiole while the lamina of $H$. sanhan is sessile. Moreover, Hornstedtia crispata has a significantly wider lamina $(10-16 \mathrm{~cm})$ than $H$. sanhan $(5-7 \mathrm{~cm})$, and the base and apex is rounded and acute rather than narrowly cuneate and acuminate as in $H$. sanhan (see table 2 for the full morphological differences between $H$. crispata and $H$. sanhan).

The main differences between the two species are in the floral morphology. Both species have bright red and ovate sterile bracts but the hairs in the lower half are white in Hornstedtia crispata while rufous (red) in H. sanhan. The most obvious similarity between the two species is the petaloid and crispate margin of the labellum (Fig. 1D \& 2J). This labellum morphology can also be observed in Hornstedtia gracilis R.M.Sm. of Sabah, Borneo (south of Palawan) but is distinct by its slender peduncle that can reach up to $1 \mathrm{~m}$ long (vs $2-4 \mathrm{~cm}$ long in $H$. crispata). This labellum morphology is also found in Hornstedtia hainanensis T.L.Wu \& S.J.Chen of Hainan, China (northwest of Palawan) but is distinct in the pink and bifid labellum (vs white and entire in $H$. crispata) and the absence of a bracteole and anther crest (vs present in H. crispata). In Hornstedtia gracilis, H. hainanensis and H. sanhan, however, only 


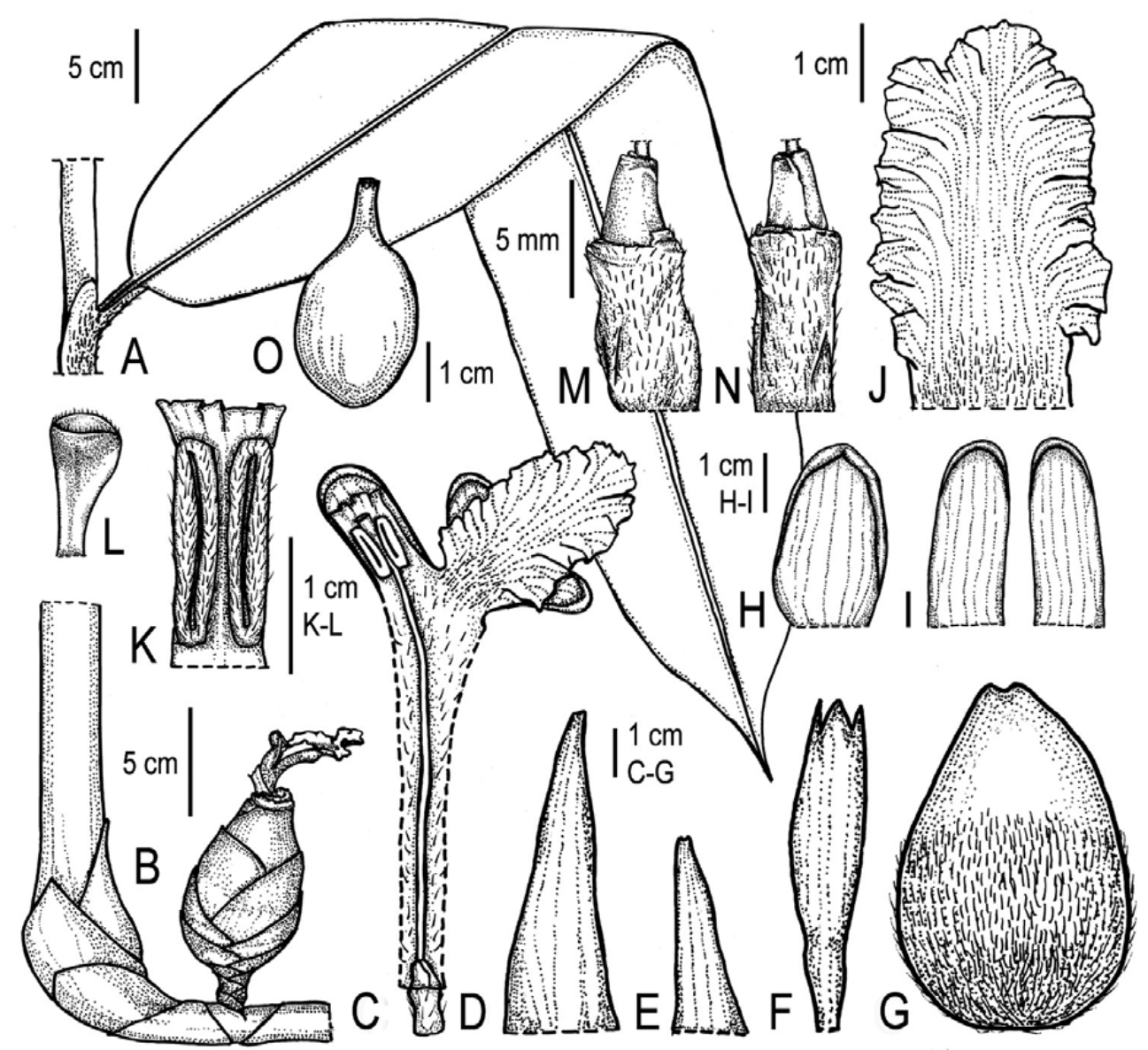

Fig. 2. Hornstedtia crispata Docot. A. Leaf. B. Base of the leafy shoot and rhizome with inflorescence. C. Flower, dissected. D. Fertile bract. E. Bracteole. F. Calyx. G. Sterile bract. H. Dorsal corolla lobe. I. Lateral corolla lobes. J. Labellum. K. Stamen. L. Stigma. M. Epigynous gland on top of ovary (abaxial). N. Adaxial. O. Immature fruit. A-N from type R.V.A. Docot et al. 0191; O from Docot et al. 0190. Both collected from Brooke's Point, Palawan. Drawn from the spirit material by K.D. Gutierrez.

$1 / 2$ or less than $3 / 4$ of the total length of the labellum has a petaloid and crispate margin in contrast to $H$. crispata in which it is present throughout its length. As a result, the labellum of Hornstedtia gracilis, $H$. hainanensis and $H$. sanhan appears spathulate rather than oblong as in $H$. crispata. Hornstedtia crispata also has a petaloid and crispate anther crest (Fig. $1 \mathrm{E} \& 2 \mathrm{~K}$ ) which is entirely absent in $H$. hainanensis and $H$. sanhan and present in $H$. gracilis as small lobes on each theca. Although the fruits are fully embedded in a juicy aril, the local people of the Palaw'an tribe do not consume them, unlike the fruits of Hornstedtia hainanensis and H. sanhan which are gathered for their edible and medicinal fruits in the regions where they occur (Newman, 1995; Ye et al., 2018). 
Table 2. Comparative morphology between Hornstedtia crispata, H. gracilis, H. hainanensis, and H. sanhan.

\begin{tabular}{|c|c|c|c|c|}
\hline $\begin{array}{l}\text { Morphological } \\
\text { characters }\end{array}$ & $\begin{array}{l}\text { Hornstedtia } \\
\text { crispata }\end{array}$ & $\begin{array}{l}\text { Hornstedtia } \\
\text { gracilis }\end{array}$ & $\begin{array}{l}\text { Hornstedtia } \\
\text { hainanensis }\end{array}$ & $\begin{array}{l}\text { Hornstedtia } \\
\text { sanhan }\end{array}$ \\
\hline Height & $4-8 \mathrm{~m}$ & $1.5-3 \mathrm{~m}$ & $1.1-2.3 \mathrm{~m}$ & $3.5-4 \mathrm{~m}$ \\
\hline Ligule & $\begin{array}{l}\text { Sericeous only at } \\
\text { the centre }\end{array}$ & Glabrous & Tomentellous & $\begin{array}{l}\text { Sericeous } \\
\text { throughout }\end{array}$ \\
\hline $\begin{array}{l}\text { Leaf } \\
\text { attachment }\end{array}$ & $\begin{array}{l}\text { Petiolate } \\
\text { (15-25 mm long) }\end{array}$ & $\begin{array}{l}\text { Petiolate } \\
\text { (c. } 10 \mathrm{~mm} \text { long) }\end{array}$ & $\begin{array}{l}\text { Subsessile } \\
\text { (c. } 5 \mathrm{~mm} \text { long) }\end{array}$ & Sessile \\
\hline Leaf width & $10-16 \mathrm{~cm}$ & $3-6 \mathrm{~cm}$ & $5-7 \mathrm{~cm}$ & $5-7 \mathrm{~cm}$ \\
\hline Leaf base & Rounded & Attenuate & $\begin{array}{l}\text { Cuneate or } \\
\text { rounded }\end{array}$ & $\begin{array}{l}\text { Narrowly } \\
\text { cuneate }\end{array}$ \\
\hline Leaf apex & Acuminate & Acute & Caudate & Acute \\
\hline Peduncle & $2-3 \mathrm{~cm}$ long & $0.2-1 \mathrm{~m}$ long & c. $0.5 \mathrm{~cm}$ long & c. $1 \mathrm{~cm}$ long \\
\hline $\begin{array}{l}\text { Colour of the } \\
\text { hairs on the } \\
\text { base of the } \\
\text { sterile bract }\end{array}$ & White & White & White & Red \\
\hline Bracteole & White & Absent & Absent & Pink or white \\
\hline $\begin{array}{l}\text { Surface of the } \\
\text { calyx }\end{array}$ & $\begin{array}{l}\text { Pubescent towards } \\
\text { the base }\end{array}$ & $\begin{array}{l}\text { Pubescent } \\
\text { towards the } \\
\text { base }\end{array}$ & $\begin{array}{l}\text { Pubescent } \\
\text { throughout }\end{array}$ & $\begin{array}{l}\text { Pubescent } \\
\text { throughout }\end{array}$ \\
\hline $\begin{array}{l}\text { Shape and apex } \\
\text { of the labellum }\end{array}$ & Oblong, entire & $\begin{array}{l}\text { Spatulate, } \\
\text { entire }\end{array}$ & $\begin{array}{l}\text { Spatulate, } \\
\text { entire }\end{array}$ & $\begin{array}{l}\text { Spatulate, } \\
\text { entire }\end{array}$ \\
\hline $\begin{array}{l}\text { Petaloid } \\
\text { margin of the } \\
\text { labellum }\end{array}$ & $\begin{array}{l}\text { Present } \\
\text { throughout the } \\
\text { length of the } \\
\text { labellum }\end{array}$ & $\begin{array}{l}\text { Present only } \\
\text { half or less than } \\
3 / 4 \text { of the length } \\
\text { of the labellum }\end{array}$ & $\begin{array}{l}\text { Present only } \\
\text { half or less than } \\
3 / 4 \text { of the length } \\
\text { of the labellum }\end{array}$ & $\begin{array}{l}\text { Present only } \\
\text { half or less than } \\
3 / 4 \text { of the length } \\
\text { of the labellum }\end{array}$ \\
\hline $\begin{array}{l}\text { Colour of the } \\
\text { anther }\end{array}$ & Whitish-red & Red & White & Pink or white \\
\hline Anther crest & $\begin{array}{l}\text { Present (petaloid } \\
\text { and crispate) }\end{array}$ & $\begin{array}{l}\text { Present (small } \\
\text { lobes on each } \\
\text { theca) }\end{array}$ & Absent & Absent \\
\hline $\begin{array}{l}\text { Epigynous } \\
\text { glands }\end{array}$ & Subglobose & Subulate & Subulate & Subulate \\
\hline
\end{tabular}




\section{New record for the Philippines}

Globba francisci Ridl., J. Linn. Soc., Bot. 42: 162 (1914). - TYPE: Malaysia, Sabah, L.S. Gibbs 2932 (lectotype BM [BM000617540], designated by Smith, Notes Roy. Bot. Gard. Edinburgh 45: 6 (1988)). (Fig. 3A \& C)

Notes. Globba francisci is usually confused with G. aurea Elmer (Fig. 3B \& D) in the forests of Palawan because both species have yellow flowers. Both are distributed from Central to Southern Palawan (Fig. 4) and usually grow together in wet rock crevices beside streams and ravines up to $1000 \mathrm{~m}$. Unfortunately, the type of Globba aurea (A.D.E. Elmer 13243) cannot be located in any herbaria but our collections perfectly match the original description of the species by Elmer (1915), including in the purplish spotted sheath and the petaloid lateral staminodes. In fact, one of the collections used in this study, C.B.M. Domingo \& R.V.A. Docot PL18-006, was collected near the type locality of $G$. aurea (Masagana Falls is c. $7.81 \mathrm{~km}$ away from Mount Pulgar $=$ Thumb Peak). Moreover, Globba francisci can be readily distinguished from $G$. aurea by the green sheath (vs purplish-spotted); narrowly-linear lamina (vs narrowlyovate); the presence of red spot in the labellum (vs absence); and subulate lateral staminodes (vs petaloid). Globba francisci belongs to Globba sect. Nudae K.Larsen subsect. Mediocalcaratae (K.Schum.) K.J.Williams while G. aurea is in Globba sect. Ceratanthera (Horan.) Petersen. The morphology of recent collections of Globba francisci in Palawan was within the range of variation of $G$. francisci in Borneo.

Specimens examined. Globba aurea. PHILIPPINES: Palawan: Puerto Princesa City, Barangay Irawan, Trail to Masagana Falls, 948'47.2"N 118 40'52.9"E, 1 Jul 2018, Domingo \& Docot PL18-006 (FEUH, USTH); El Nido, Barangay Pasadena, Trail to Nagkalit-kalit Falls, 11'15'24.0"N 119²6'11.8"E, 4 Jul 2018, Zamudio \& Docot SZ18-737 (FEUH, USTH); Brooke's Point, Barangay Malis, Mount Mantalingajan, 844'09.1"N, 117 40'17.4"E, $884 \mathrm{~m}$, 27 Sept 2018, Docot et al. 0188 (FEUH, L, USTH).

Globba francisci. MALAYSIA: Sabah: Tenom, Jan 1910, Gibbs 2932 (BM); Trusmadi Forest Reserve, South of Sino, Aug 1977, Gardner 68 (E); Ranau, Lohan River, 900 m, 5 Apr 1984, Beaman 9209 (E); Poring Hot Springs, 18 June 1986, Smith 33/86 (E); Bukit Tempadong, along Segama River, 150 m, 11 Jun 1984, Beaman 10080 (E). Sarawak: Miri Division, Gunung Mulu National Park, Gua Payau, 100 m, 19 Nov 1977, Argent \& Kerby 802 (E); Miri Division, Gunung Mulu National Park, Gua Payau, 100 m, 31 July 1978, Jermy 14229 (E); Lobang Rusa, 7 Oct 1977, Sinclair S 31806 (E).

PHILIPPINES: Palawan: Puerto Princesa City, Barangay Iwahig, Thumb Peak (formerly Mount Pulgar), 946'21.5"N, 118 39'44.1"E, 1 Oct 2017, Docot et al. 0111 (L, NY, PNH, USTH); Barangay Irawan, Trail to Masagana Falls, 948'45.9"N 118 40'50.3"E, 1 Jul 2018 , Domingo \& Docot PL18-007 (FEUH, USTH); Brooke's Point, Barangay Malis, Mount Mantalingajan, 842'30.0"N 11740'57.0"E, 268 m, 27 Sep 2018, Docot et al. 0183 (FEUH, PNH, USTH). 


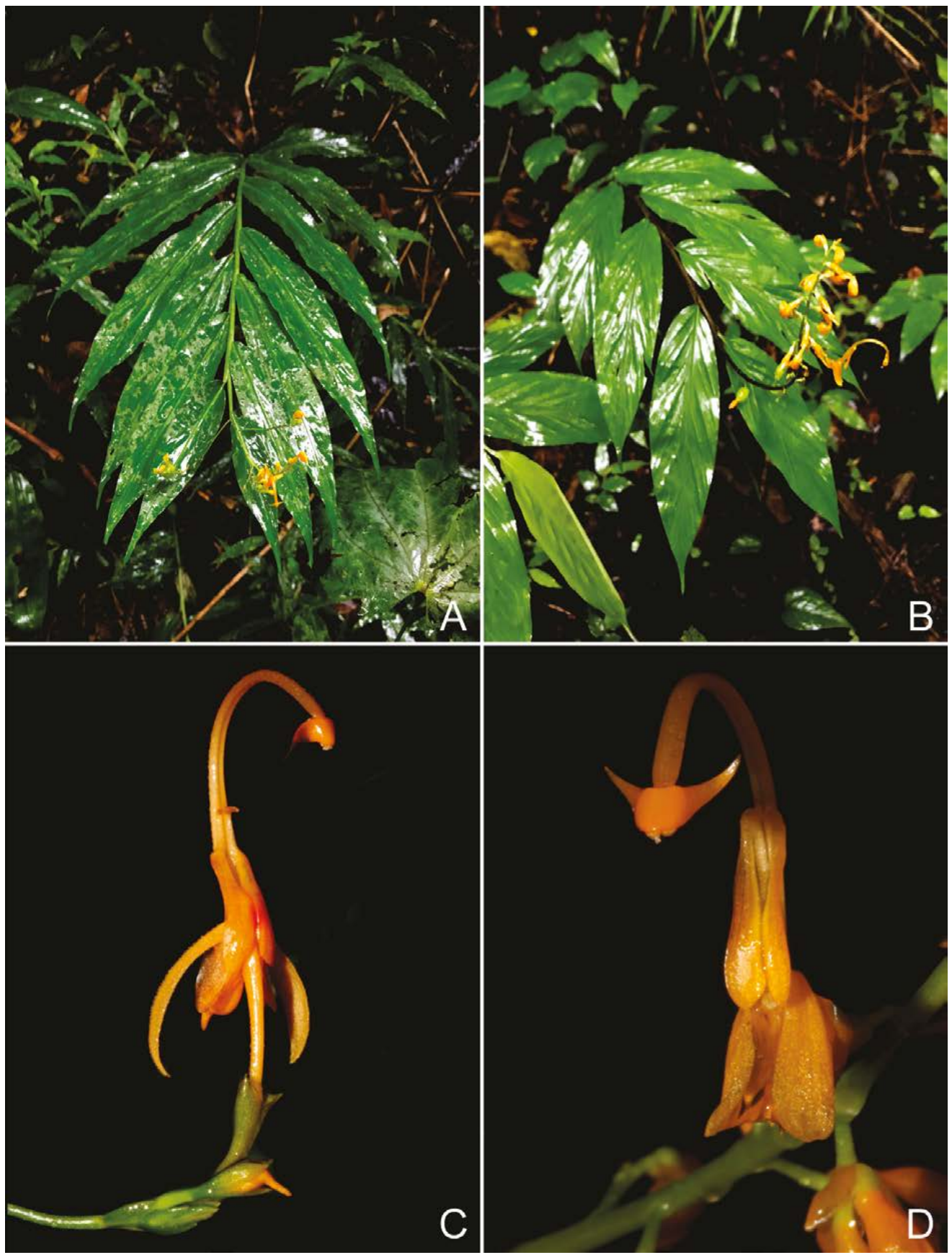

Fig. 3. A \& C. Globba francisci Ridl. A. Habit. C. Flower. B \& D. Globba aurea Elmer. B. Habit. D. Flower. A \& C from Docot et al. 0111; B \& D from Domingo \& Docot PL18-006. All from Puerto Princesa City, Palawan (Photos: R.V.A. Docot). 


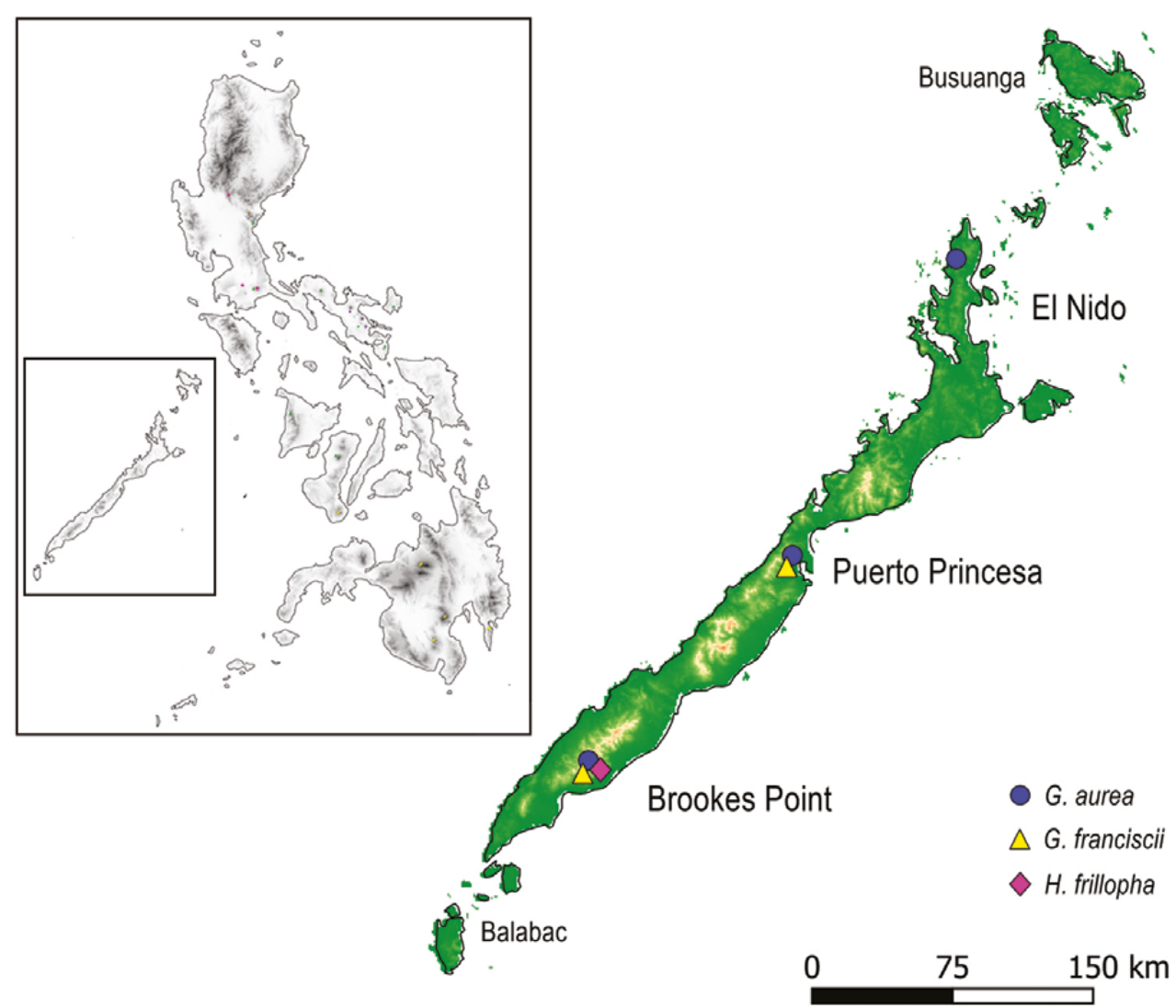

Fig. 4. Distribution map of Globba aurea Elmer, G. francisci Ridl. and Hornstedtia crispata Docot in the province of Palawan.

ACKNOWLEDGEMENTS. We thank the keepers of the herbaria of BM, E, FEUH, K, PNH, and USTH for allowing us to view and examine their collections. Collection permits were issued by the Palawan Council for Sustainable Development (PCSD) with the help of S.G.S. Zamudio and L.C.P. Santiago upon facilitation. We thank R.A.A. Bustamante of Philippine Taxonomic Initiative (PTI), W. Cabanillas, G.C.V. Gamus, T.J.R. Pangilinan, D.K.P Adesas, M.J.B. Grecia, N.A.J.C. Flores, Barangay Malis, and the Palaw'an tribe for their hospitality and help during fieldwork; the FEU University Research Centre (URC) headed by S.L. Yap for the facilities and laboratory equipment; K.D. Gutierrez for the drawings; S. Sangvirotjanapat for the useful information and for helping us identify our Globba collections; and the Systematic Research Fund (SRF) of the Linnaean Society of London and Systematics Association for the financial support in our Mount Mantalingajan, Palawan fieldwork. 


\section{References}

Acma, F.M., Mendez, N.P., Lagunday, N.E., \& Amoroso, V.B. (2019). New record of Plagiostachys albiflora Ridl. (Zingiberaceae) in the Philippines. Modern Phytomorphol. 13: 5-8.

Ambida, J.H.B., Alviar, A.M.A., Co, P.S.A., Concepcion, F.G.M., Banag, C.I. \& Docot, R.V.A. (2018). A new species of Vanoverberghia (Zingiberaceae) from the Philippines. Blumea 63: $130-134$.

Bachman, S., Moat, J., Hill, A.W., de Torre, J. \& Scott, B. (2011). Supporting Red List threat assessments with GeoCAT: geospatial conservation assessment tool. In: Smith, V. \& Penev, L. (eds) e-Infrastructures for data publishing in biodiversity Science. ZooKeys 150: $117-126$

Beentje, H. (2012). The Kew Plant Glossary, an illustrated dictionary of plant terms, revised edition. Kew: Royal Botanic Gardens, Kew Publishing.

Brown, R.M. \& Guttman, S.I. (2002). Phylogenetic systematics of the Rana signata complex of Philippine and Bornean stream frogs: Reconsideration of Huxley's modification of Wallace's Line at the Oriental-Australian faunal zone interface. Biol. J. Linn. Soc. 76: 393-461.

Docot, R.V.A., Banag, C.I., Funakoshi, H., Tandang, D.N. \& Poulsen, A.D. (2019a). Recircumscription and revision of the genus Vanoverberghia (Zingiberaceae). Blumea 64(2): 140-157.

Docot, R.V.A, Banag, C.I., \& Poulsen, A.D. (2019b). Reinstatement and revision of Adelmeria (Zingiberaceae) endemic in the Philippines. Taxon 68(2): in press.

Elmer, A.D.E. (1915). Notes and descriptions of Zingiberaceae. Leafl. Philipp. Bot. 2: 2885-2919.

Fernandez, J., Fernandez, F. \& Fernandez-Legazpi, E.I. (2002). Palawan flora and fauna, revised edition. Palawan Tropical Forestry Protection Programme.

Gagnepain, M.F. (1901). Revision des genres Mantisia et Globba (Zingibéreés) de l'herbier du museum. Bull. Soc. Bot. France 48: 201-216.

Heaney, L.R. (1986). Biogeography of mammals in SE Asia: Estimates of rates of colonization, extinction and speciation. Biol. J. Linn. Soc. 28: 127-165.

Hughes, M., Rubite, R., Blanc, P., Chung, K.-F. \& Peng, C.-I. (2015). The miocene to pleistoscene colonization of the Philippine archipelago by Begonia Sect. Baryandra (Begoniaceae). Amer. J. Bot. 102(5): 695-706.

IUCN Standards and Petitions Subcommittee (2016). Guidelines for using the IUCN Red List categories and criteria, ver. 12. https://www.iucnredlist.org/ documents/RedListGuidelines. Accessed 27 Nov. 2018.

Lamb, A., Gobilik, J., Ardiyani, M. \& Poulsen, A.D. (2013). A guide to gingers of Borneo. Kota Kinabalu: Natural History Publications (Borneo).

Leong-Škorničková, J. \& Newman, M. (2015). Gingers of Cambodia, Laos \& Vietnam. Singapore: Singapore Botanic Gardens, National Parks Board.

Leong-Škorničková, J., Nguyễn, Q.B., Trần, H.Đ. \& Záveská, E. (2016). Etlingera poulsenii and Hornstedtia bella (Zingiberaceae: Alpinieae), two new species from central Vietnam. Gard. Bull. Singapore 68(2): 287-297.

Merrill, E.D. (1923). An enumeration of Philippine flowering plants, vol. 1. Manila, Philippines: Bureau of Science.

Naive, M.A.K. (2017). Etlingera hamiguitanensis (Zingiberaceae; Alpinieae), a new ginger species from Davao Oriental, Philippines. Taiwania 62(4): 340-344. 
Naive, M.A.K. \& Alejandro, G.J.D. (2018). Hornstedtia garbosa (Zingiberaceae: Alpinieae), a new species from Mindanao, Philippines. Phytotaxa 347(2): 183-188.

Naive, M.A.K., Bautista, C.Y.V., Cabra, J.A.T., Insigne, A.N. \& Alejandro, G.J.D. (2018). Hornstedtia annadeguzmaniae (Zingiberaceae), a new species from the Philippines. Ann. Bot. Fenn. 56: 101-105.

Newman, M. (1995). A new species of Hornstedtia (Zingiberaceae) from Vietnam. Kew Bull. 50(1): 125-127.

PCSDS (2015). State of the Environment 2015 Updates, Province of Palawan (UNESCO Man and Biosphere Reserve), Philippines. Puerto Princesa: Palawan Council for Sustainable Development.

Pelser, P.B., Barcelona, J.F. \& Nickrent, D.L. (eds) (2011 onwards). Co's Digital Flora of the Philippines. http://www.philippineplants.org. Accessed 18 Nov. 2018.

Poulsen, A.D. \& Docot, R.V.A. (2018). How many Etlingera species are there in the Philippines? Edinburgh J. Bot. 75(3) 1-12.

Quantum GIS Development Team (2016). Quantum GIS Geographic Information System. Open Source Geospatial Foundation Project. http://qgis.osgeo.org.

Ridley, H.N. (1905). Scitimineae Philippinenses. Publ. Bur. Sci. Gov. Lab. 35(1): 83-87.

Ridley, H.N. (1909). The Scitamineae of the Philippine Islands. Philipp. J. Sci., C 4: 155-199

Smith, R.M. (1985). A review of Bornean Zingiberaceae: I (Alpinieae p.p.). Notes Roy. Bot. Gard. Edinburgh 42: 261-314.

Smith, R.M. (1988). A review of Bornean Zingiberaceae: IV (Globbeae). Notes Roy. Bot. Gard. Edinburgh 45: 1-19.

Sopsop, L.B. \& Buot, I. (2009). The endangered plants of Palawan Island, Philippines. Asia Life Sci. 18: 251-279.

Thiers, B. (continuously updated). Index Herbariorum: A global directory of public herbaria and associated staff. New York Botanical Garden's Virtual Herbarium. http://sweetgum. nybg.org/science/ih/. Accessed 17 Nov. 2018.

Williams, K.J., Kress, W.J. \& Manos, P.S. (2004). The phylogeny, evolution, and classification of the genus Globba and the tribe Globbeae (Zingiberaceae): appendages do matter. Amer. J. Bot. 91(1): 100-114.

Woodruff, D.S. (2010). Biogeography and conservation in Southeast Asia: How 2.7 million years of repeated environmental fluctuations affect today's patterns and the future of the remaining refugial-phase biodiversity. Biodivers. \& Conservation 19: 919-941.

Ye, X.-E., Bai, L., Ye, Y.-S., Xia, N.-H. \& Leong-Škorničková, J. (2018). Taxonomic studies of Amomum (Zingiberaceae) in China II: transfer of Hornstedtia tibetica to Amomum and supplementary description of H. hainanensis. Pl. Syst. Evol. 304: 1165-1180.

Zingiberaceae Resource Centre. (2019). Royal Botanic Garden Edinburgh. http://padme.rbge. org.uk/ZRC/welcome. Accessed 19 Jan. 2019. 
